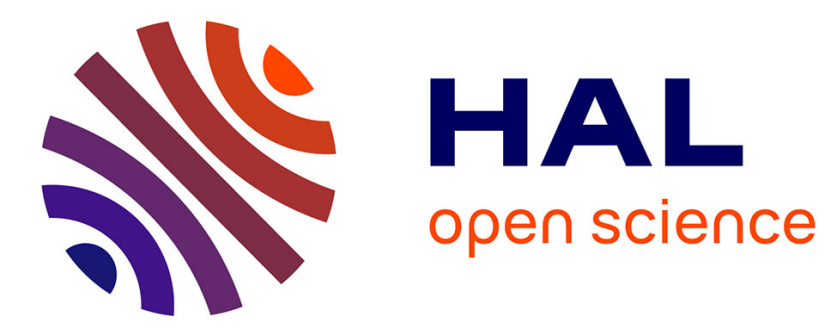

\title{
Impact of compensation on boron and oxygen-related degradation of upgraded metallurgical-grade silicon solar cells
}

\author{
Maxime Forster, J. Degoulange, R. Einhaus, G. Galbiati, E. Rougieux, A. \\ Cuevas, Erwann Fourmond, Mustapha Lemiti
}

\section{To cite this version:}

Maxime Forster, J. Degoulange, R. Einhaus, G. Galbiati, E. Rougieux, et al.. Impact of compensation on boron and oxygen-related degradation of upgraded metallurgical-grade silicon solar cells. Solar Energy Materials and Solar Cells, 2014, 120, pp.390-395. hal-01490336

\section{HAL Id: hal-01490336 https://hal.science/hal-01490336}

Submitted on 12 Feb 2018

HAL is a multi-disciplinary open access archive for the deposit and dissemination of scientific research documents, whether they are published or not. The documents may come from teaching and research institutions in France or abroad, or from public or private research centers.
L'archive ouverte pluridisciplinaire HAL, est destinée au dépôt et à la diffusion de documents scientifiques de niveau recherche, publiés ou non, émanant des établissements d'enseignement et de recherche français ou étrangers, des laboratoires publics ou privés. 
1

\title{
Impact of compensation on the boron and oxygen-related degradation of upgraded metallurgical-grade silicon solar cells
}

Maxime Forster ${ }^{1}$, Pierre Wagner ${ }^{1,2}$, Julien Degoulange ${ }^{1}$, Roland Einhaus ${ }^{1}$, Giuseppe Galbiati $^{4}$, Fiacre Emile Rougieux ${ }^{3}$, Andrés Cuevas ${ }^{3}$, Erwann Fourmond ${ }^{2}$ and Mustapha Lemiti ${ }^{2}$

1. APOLLON SOLAR, 66 cours Charlemagne, 69002 Lyon, France

2. INSA de LYON, INL, 7 av. J. Capelle, 69621 Villeurbanne Cedex, France

3. ISC Konstanz

4. Research School of Engineering, The Australian National University, Canberra ACT 0200, Australia

\begin{abstract}
:
This paper deals with the impact of dopant compensation on the degradation of carrier lifetime and solar cells performance due to the boron-oxygen defect. The boron-oxygen defect density evaluated by lifetime measurements before and after degradation is systematically found proportional to the total boron concentration, showing that compensation cannot reduce light-induced degradation. This result is confirmed by a comparison of upgraded-metallurgical grade silicon solar cells having identical boron, oxygen and carbon but different compensation levels and in which the degradation is found more severe when the compensation is stronger.
\end{abstract}

Keywords: 
Czochralski growth, dopant compensation, boron, phosphorus, gallium, oxygen, lightinduced degradation, solar cells. 


\section{Introduction}

Simultaneous presence of boron (B) and oxygen (O) in crystalline silicon ( $\mathrm{Si}$ ) is known to result in the existence of a strong recombination center - the boron-oxygen (BO) defect - which forms or is activated under excess carrier injection. In its active state, the $\mathrm{BO}$ defect dominates bulk recombination in B-doped cast or Czochralski (Cz)-grown $\mathrm{Si}$, on which most of the photovoltaic industry is based. As a consequence, this defect currently represents one of the major wafer-related limitations of the performance of state-of-the-art industrial $p$-type Si solar cells [1].

Upgraded metallurgical-grade (UMG) Si solar cells are usually more affected by the BO defect, due to larger B concentration. Recent studies, however, found that the BO defect density was proportional in $p$-type $\mathrm{Si}$ to the net doping, rather than to the total $\mathrm{B}$ concentration, meaning that it could thus be reduced by compensation [2-5]. This finding was more recently contradicted by a study of the BOrelated light-induced degradation of compensated Si solar cells, of which the severity was found to depend on the total B concentration [6]. With Ga co-doping offering an efficient tool for compensation engineering [7-9], it becomes important to clarify whether compensation can effectively be employed to mitigate the impact of the BO defect and thus improve the final performance of UMG-Si solar cells.

Another lately debated issue is the composition of the BO defect complex. Guided by observations that the BO defect density depends on the net doping - or majority carrier density - Voronkov and Falster [10] proposed a model in which the defect complex is made with interstitial boron $\left(\mathrm{B}_{\mathrm{i}}\right)$. The dependence of the BO defect density was thereby explained by the proportionality of the solubility of positively charged $\mathrm{B}_{\mathrm{i}}$ to the hole concentration, during the last phase of crystal cooling. Measurements in $n$-type compensated Si [11-13] and in Si co-doped with B and Ga [14] were nonetheless found 
inconsistent with the involvement of $\mathrm{B}_{\mathrm{i}}$ but rather suggested the participation of substitutional $\mathrm{B}$. In addition, recent calculations found that the concentration of $\mathrm{B}_{\mathrm{i}}$ was too low to explain the observed lifetime degradation and that the calculated characteristics of the $\mathrm{B}_{\mathrm{i}} \mathrm{O}_{2 \mathrm{i}}$ complex were inconsistent with those measured by lifetime spectroscopy for the BO defect [15]. On the other hand, participation of substitutional boron $\left(\mathrm{B}_{\mathrm{s}}\right)$ in the $\mathrm{BO}$ defect complex remains very difficult to reconcile with the linearity of the defect density to the net doping [16].

In the present work, we aim at verifying the effect of compensation on the $\mathrm{BO}$ recombination center and clarifying the composition of the defect complex. In a first experiment, we study the BO-related lifetime degradation in Si samples with a wide range of dopant concentrations and compensation levels. We evaluate the oxygen-normalized effective BO defect density and find it to depend on the total boron concentration, demonstrating the involvement of substitutional boron in the defect complex. In a second experiment, we crystallize two different $\mathrm{Cz}$ ingots having identical $\mathrm{B}, \mathrm{O}$ and $\mathrm{C}$ profiles but different compensation levels. Then, we fabricate solar cells with wafers from both ingots and measure their behavior under illumination. We find that the activation of the BO defect leads to stronger performance degradation in solar cells made with heavily compensated $\mathrm{Si}$ than with lightly compensated Si. This experiment unambiguously shows that compensation does not mitigate the impact of the BO defect on solar cells but on the contrary worsens it.

\section{Experimental methods}

\subsection{Study of the lifetime degradation in compensated silicon wafers}

This study was carried out on p-type Cz-Si samples co-doped with Ga and B, B and P or B, P and Ga. These samples originate from a batch of $\langle 100>$-oriented Si ingots which were crystallized using the Czochralski pulling technique. They were grown using electronic-grade (EG)-Si to which were 
added various concentrations of $\mathrm{B}, \mathrm{P}$ and $\mathrm{Ga}$. In each sample, $p_{0}$ was deduced from Hall effect measurement, assuming a Hall factor of $r_{\mathrm{H}}=0.75$ [17]. [B] was deduced from the sample's position in the ingot, and from the initial concentration of B added into the Si melt, using Scheil's equation [18]. Together with uncompensated B-doped, P-doped and Ga-doped controls, these samples were subsequently acid etched to remove saw damage, RCA cleaned, and underwent a phosphorus diffusion gettering at $820^{\circ} \mathrm{C}$ to dissolve oxygen-related thermal donors and eliminate metallic impurities. This ensures that there is no or very little impact of FeB and FeGa pairs during the degradation experiment. Diffused regions were then removed by an additional acid etch and samples were RCA cleaned before being coated on both sides by hydrogenated $\mathrm{Si}$ nitride $\left(\mathrm{SiN}_{\mathrm{x}}: \mathrm{H}\right)$ at $235{ }^{\circ} \mathrm{C}$, using plasma-enhanced chemical vapor deposition (PECVD).

After deposition, samples were annealed in the dark at $200{ }^{\circ} \mathrm{C}$ under air ambient during $30 \mathrm{~min}$, in order to annihilate the boron-oxygen defect. The effective lifetime was then measured using inductively-coupled photo-conductance decay [19], immediately after annealing $\left(\tau_{0}\right)$ and after different times $t$ of illumination under a $10 \mathrm{~mW} / \mathrm{cm}^{2}$ halogen lamp at $25-27^{\circ} \mathrm{C}$.

A fit to Dannhauser and Krause's mobility sum measurements [20-22] is commonly used to convert photo-conductance data into excess carrier density for injection-dependent lifetime measurements [19]. This fit is accurate in uncompensated $\mathrm{Si}[23]$ but overestimates the mobility sum in compensated $\mathrm{Si}$ [ref Ziv]. To account for that lower mobility in our samples, we adjust the doping used as input in the fit to Dannhauser and Krause's mobility so that it yields the same low-injection mobility sum as we previously measured in our compensated samples (see [24]).

The effective lifetime degraded under illumination in all samples except for those which did not contain $\mathrm{B}$, in which it remained stable. This proves that the surface passivation quality of the $\mathrm{SiN}_{\mathrm{x}}: \mathrm{H}$ layer did not change throughout the experiment. The observed degradation in samples containing B can 
thus be attributed to a decrease of the bulk lifetime. After complete degradation, i.e. after saturation of the measured lifetime to its final value $\tau_{\text {deg }}$, the effective $\mathrm{BO}$ defect density is calculated using the following expression:

$$
N_{t}^{*}=\frac{1}{\tau_{\operatorname{deg}}}-\frac{1}{\tau_{0}}
$$

in which $\tau_{\text {deg }}$ and $\tau_{0}$ are taken at a fixed injection level of $\Delta n=0.1 \times p_{0}$. It is well known that the effective defect density after complete degradation $N_{\mathrm{t}, \mathrm{sat}} *$ displays a quadratic dependence on $\left[\mathrm{O}_{\mathrm{i}}\right]$ [25]. This dependence is thought to be due to the participation of oxygen dimers which are themselves present in a concentration proportional to $\left[\mathrm{O}_{\mathrm{i}}\right]$ squared [26]. Since we intend to study the impact of dopants on the $\mathrm{BO}$ defect density, a more relevant parameter to focus on is:

$$
N_{B C}=\frac{N_{t, s a t}^{*}}{\left[\mathrm{O}_{i}\right]^{2}}
$$

This oxygen-normalized parameter reflects the influence of defect components (such as $[\mathrm{B}]$ or $p_{0}$ ) not directly related to $\left[\mathrm{O}_{\mathrm{i}}\right]$. To evaluate $N_{\mathrm{BC}}$ in our samples, $\mathrm{SiN}_{\mathrm{x}}: \mathrm{H}$ layers were etched off in hydrofluoric acid after the degradation experiment and $\left[\mathrm{O}_{\mathrm{i}}\right]$ was measured by Fourier transform infrared spectroscopy (FTIR).

\subsection{Study of the degradation of compensated Si solar cells}

\section{a. Feedstock preparation}

For this study, we used 30kg of PHOTOSIL UMG-Si [27-29]. The starting metallurgical-grade (MG)-Si was produced by FerroPEM, with careful selection of raw materials, i.e. silica and carbon, enabling to limit the initial impurity concentration. A first segregation treatment was applied during solidification of this MG-Si straight away after carbothermic reduction, decreasing the concentration of phosphorus and metallic impurities. The resulting material was then transferred to the PHOTOSIL 
facilities where it was purified according to the standard PHOTOSIL process [27-29], involving a plasma treatment to remove $\mathrm{B}$ and segregations to remove $\mathrm{P}$ and metallic impurities. After purification, the Si feedstock contains 0.25 ppmw of B and 0.60 ppmw of P.

\section{b. Crystallization}

This lot of $30 \mathrm{~kg}$ of PHOTOSIL UMG-Si was divided into two batches of $15 \mathrm{~kg}$, considered as identical in terms of impurity concentration. These two batches were used to grow two different $<100>$-oriented Si ingots of about $160 \mathrm{~mm}$ in diameter using the Czochralski crystallization technique. Both crystals were pulled with an average rate of $v=0.7 \mathrm{~mm} / \mathrm{min}$, a crystal rotation rate of $w_{\text {cryst }}=1.26$ rad. $\mathrm{s}^{-1}$ and an inverse rotation of the crucible with a rate of $w_{\text {cruc }}=0.84 \mathrm{rad} . \mathrm{s}^{-1}$ under an Ar pressure of 20 torr.

The first crystal, which we will refer to as Cz\#U1, was grown without addition of any dopants aside from those already contained in the UMG-Si. The second ingot, called Cz\#U2, was grown using the same crystallization process except for that we added 1.4 ppmw of $\mathrm{P}$ and 85 ppmw of Ga into the crucible before melting of the $\mathrm{Si}$. The addition of $\mathrm{P}$ enables to reduce the net doping while the addition of Ga serves to maintain fully $p$-type ingot. Note that without the addition of Ga, adding $\mathrm{P}$ into the $\mathrm{Si}$ melt would reduce the $p$-type fraction of the ingot and thus the ingot yield. After crystallization, both ingots were shaped into $125 \times 125 \mathrm{~mm}^{2}$ pseudo-square bricks and the resistivity and carrier lifetime profiles were measured respectively by Eddy current and $\mu \mathrm{W}-\mathrm{PCD}$ along the length of each brick.

\section{c. Solar cells fabrication and characterization}

Both ingots were then cut by a slurry wire saw into wafers with a thickness of about $200 \mu \mathrm{m}$. Hall effect measurements were carried out on $2 \times 2 \mathrm{~cm}^{2}$ samples cut into wafers taken from different heights along each ingot. 
Industrial type screen printed solar cells with full area phosphorus front side diffusion and Al back contact were fabricated at ISC Konstanz with 40 wafers of each one of the two ingots, evenly distributed along their length. Uncompensated B-doped EG-Si control wafers were processed simultaneously -10 wafers with a resistivity of $1.5 \Omega \cdot \mathrm{cm}$ and 10 wafers with a resistivity of $3.0 \Omega \cdot \mathrm{cm}$.

The current-voltage (I-V) characteristics of these solar cells were then measured using a flash I-V tester before degradation and after $60 \mathrm{~h}$ under illumination at a temperature of $60^{\circ} \mathrm{C}$.

\section{Results and discussion}

\subsection{BO defect density in compensated Si wafers}

To observe separately the potential influences of [B] or $p_{0}$ on $N_{\mathrm{BC}}$, we selected among our samples groups with equal $p_{0}$ and other groups with equal $[\mathrm{B}]$. To study the influence of [B], we found two groups of samples with iso- $p_{0}$ : one with 7 samples having $p_{0}=(2.0 \pm 0.3) \times 10^{16} \mathrm{~cm}^{-3}$ and one with 3 samples with $p_{0}=(5.7 \pm 0.4) \times 10^{16} \mathrm{~cm}^{-3}$. Plotting $N_{\mathrm{BC}}$ against $[\mathrm{B}]$ in these two groups (Figure 1-(a)) reveals a clear correlation between these two quantities. To study the influence of $p_{0}$, we found two groups of 4 samples, the first one with $[\mathrm{B}]=(1.7 \pm 0.06) \times 10^{17} \mathrm{~cm}^{-3}$ and the second one with $[\mathrm{B}]=$ $(3.6 \pm 0.6) \times 10^{16} \mathrm{~cm}^{-3}$. In Figure 1-(b), we see an increase of $N_{\mathrm{BC}}$ with $p_{0}$ in samples with $[\mathrm{B}]=1.7 \pm$ $0.06 \times 10^{17} \mathrm{~cm}^{-3}$ and no clear trend in samples with $[\mathrm{B}]=(3.6 \pm 0.6) \times 10^{17} \mathrm{~cm}^{-3}$.

The clear correlation between $N_{\mathrm{BC}}$ and [B] unambiguously indicates the participation of substitutional boron $\mathrm{B}_{\mathrm{s}}$ in the $\mathrm{BO}$ defect complex, since there is no other means through which $[\mathrm{B}]$ can influence $N_{\mathrm{BC}}$. We have proposed in [14], as an alternative explanation to the involvement of $\mathrm{B}_{\mathrm{s}}$ in the complex, that $\left[\mathrm{B}_{\mathrm{i}}\right]$ or $\left[\mathrm{O}_{2 \mathrm{i}}\right]$ could be reduced due to the presence of $\mathrm{Ga}$. This could have justified, keeping $\mathrm{B}_{\mathrm{i}} \mathrm{O}_{2 \mathrm{i}}$ as the defect complex, the lower values for $N_{\mathrm{BC}}$ in $\mathrm{Si}$ co-doped with $\mathrm{Ga}$ and $\mathrm{B}$ than in uncompensated B-doped Si with the same $p_{0}$. Such a proposition can be discarded in the views of the 
present results, since in samples co-doped with $\mathrm{B}, \mathrm{P}$ and $\mathrm{Ga}$ and in which $p_{0}<[\mathrm{B}], N_{\mathrm{BC}}$ is still measured to be proportional to [B]. The only remaining plausible interpretation for the variation of $N_{\mathrm{BC}}$ with $[\mathrm{B}]$ is hence the participation of $\mathrm{B}_{\mathrm{s}}$ in the $\mathrm{BO}$ complex.

\subsection{Doping and lifetime profiles}

As can be seen on Figure 2-(a), the net doping is significantly lower along most of ingot Cz\#U2 than along Cz\#U1. This is due to compensation by larger concentration of $\mathrm{P}$ atoms in this ingot, while $p$ type conductivity is maintained along the entire crystal length due to the presence of Ga. This lower net doping leads to a higher resistivity, with an average of $2.5 \Omega \cdot \mathrm{cm}$ along the first $70 \%$ of ingot Cz\#U2 against $1.2 \Omega \cdot \mathrm{cm}$ for ingot Cz\#U1 (Figure 2-(b)).

Because both ingots Cz\#U1 and Cz\#U2 are grown with the same crystallization process, in the same conditions and with the same $\mathrm{Si}$ feedstock, they have identical impurity profiles apart from $\mathrm{P}$ and $\mathrm{Ga}$ which were added in Cz\#U2. This means that two wafers taken from the same position in ingot Cz\#U1 and Cz\#U2 have the same B, O and $\mathrm{C}$ concentrations, but different $p_{0}$. This will enable us to study in the next section the impact of reducing $p_{0}$ by compensation on light-induced degradation of solar cells without varying other parameters affecting the BO defect.

The carrier lifetime measured along both bricks is shown on Figure 3. Because of the smaller majority carrier density in $\mathrm{Cz \# U} 2$, the measured lifetime is about 3 times higher in this ingot than in Cz\#U1. This illustrates well the positive outcome of compensation on carrier lifetime before lightinduced degradation, which was previously reported and analyzed by several groups [30-32].

\subsection{I-V characteristics \\ d. Before degradation}

Measured I-V characteristics of fabricated solar cells are shown in Figure 4. As can be seen, solar cells made with wafers from Cz\#U2 have on average slightly better $J_{\text {sc }}$ and slightly worse $V_{\mathrm{oc}}$ than 
Cz\#U1. The slightly better $J_{\mathrm{sc}}$ for Cz\#U2 illustrates the positive impact of increasing compensation on the minority carrier diffusion length. Because the lifetime enhancement due to compensation outweighs the reduction in minority carrier mobility, the minority carrier diffusion length increases with compensation [9], and so does $J_{\mathrm{sc}}$. On the other hand, the lower $V_{\mathrm{oc}}$ for ingot Cz\#U2 than for Cz\#U1 illustrates that in the expression of $V_{\mathrm{oc}}$ (Equation 3), the reduction in $p_{0}$ due to compensation slightly outweighs the increase in $\Delta n$ resulting from the carrier lifetime improvement.

$$
V_{o c} \approx \frac{k T}{q} \ln \left(\frac{\Delta n+\left(\Delta n+p_{0}\right)}{n_{i}^{2}}\right)
$$

Overall, the differences in $J_{\mathrm{sc}}$ and $V_{\mathrm{oc}}$ between Cz\#U1 and Cz\#U2 cancel each other out and both ingots yield similar solar cell conversion efficiencies $\eta$ of respectively $17.94 \%$ and $17.92 \%$ on average. This result shows that by using Ga co-doping, it is possible to tolerate a much higher $\mathrm{P}$ concentration $(2$ ppmw in Cz\#U2 instead of 0.6 ppmw in Cz\#U1) in the Si feedstock, without compromising neither the ingot yield nor the solar cells performance. Such a finding is very positive because it strongly releases the specifications on $\mathrm{P}$ concentration, of which the reduction represents an important cost element of UMG-Si purification. Also note that the gap between the average efficiency of EG-Si and UMG-Si solar cells is less than $0.3 \%$, showing that UMG-Si is an appropriate material for making highefficiency solar cells.

\section{e. After degradation}

Figure 5 shows the efficiency of 6 pairs of solar cells taken from equivalent positions along ingots Cz\#U1 and Cz\#U2 before and after light-induced degradation. Before light-induced degradation, solar cells from both ingots have similar efficiency. After activation of the BO defect, the efficiency degrades in both ingots but the degradation is significantly stronger in ingot Cz\#U2, down to $16.4 \%$ on average against $17 \%$ in $\mathrm{Cz} \# \mathrm{U} 1$. This confirms our previous finding that the BO defect density depends 
on the total boron concentration rather than on the net doping. Both ingots Cz\#U1 and CZ\#U2 having the same $[\mathrm{B}]$ profile, they also have the same BO defect density profile. Since the BO recombination center is a deep level with a capture cross section for electrons which does not differ strongly from that for holes [33] (capture cross section ratio of about 10 for the BO defect against around 1000 for interstitial iron), its recombination activity does not vary much with the majority carrier density [34]. This means that carrier lifetime after degradation depends only on the BO defect density and should therefore be the same in ingots Cz\#U1 and Cz\#U2. On the other hand, due to stronger compensation in Cz\#U2, the majority carrier density and the minority carrier mobility are lower in this ingot. This leads to lower open-circuit voltage and short-circuit current in solar cells made with wafers from Cz\#U2. On the other hand, if the BO defect density was proportional to the net doping, carrier lifetime should be twice longer in Cz\#U2 than in Cz\#U1 and both ingots should thus have similar efficiency.

\section{Conclusion}

In summary, we have shown through the analysis of the lifetime degradation in samples with a wide variety of doping and compensation levels that the BO defect density is in general proportional to the total boron concentration, rather than to the net doping. Such dependence implies the participation of substitutional boron in the defect complex and means that light-induced degradation cannot be mitigated by compensation. This finding is confirmed by a comparison between two UMG-Si Cz ingots having identical $\mathrm{B}, \mathrm{O}$ and $\mathrm{C}$ profiles but different compensation levels. Because both ingots have identical carrier lifetime profiles after degradation the lower majority carrier density and minority carrier mobility in the heavily compensated ingot lead to lower open-circuit voltage, short-circuit current and hence conversion efficiency. This experiment unambiguously shows that whatever the nature of the $\mathrm{BO}$ defect, its impact cannot be diminished by compensation. 


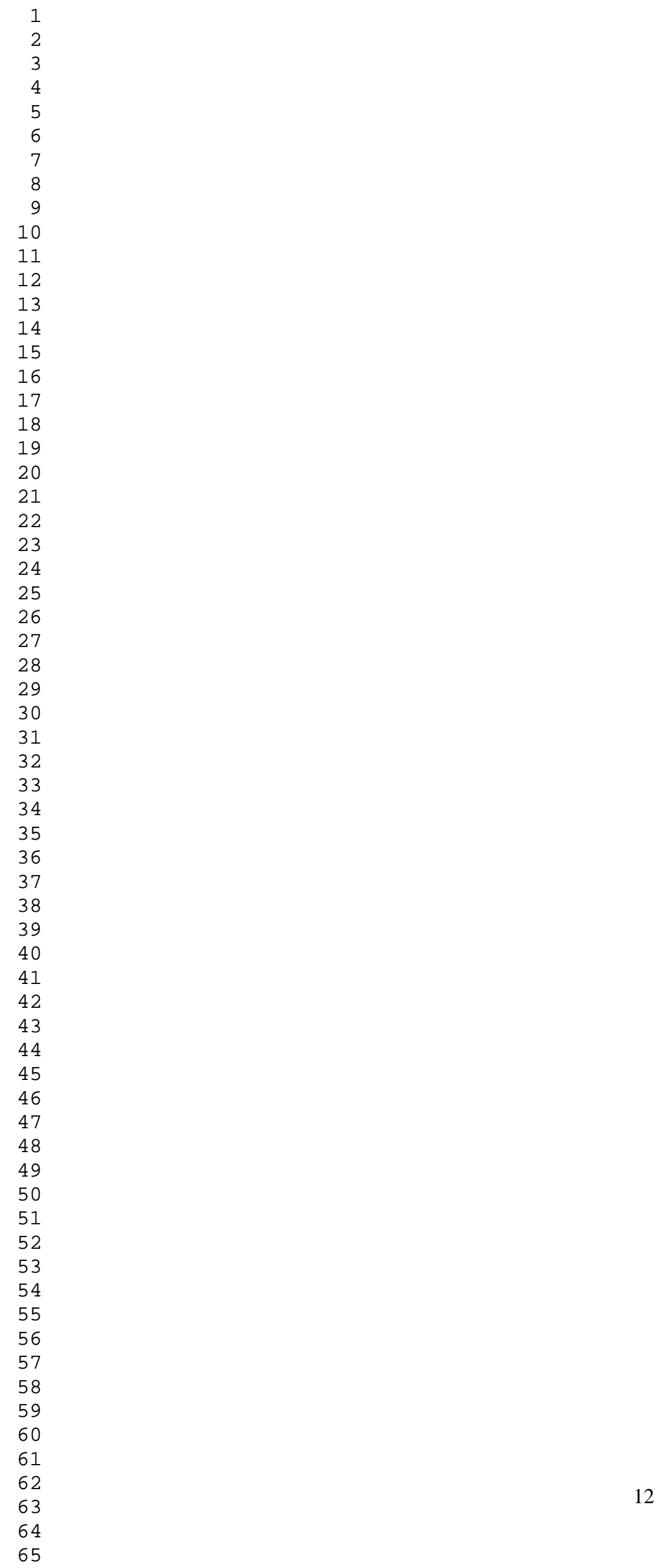




\section{Figure captions:}

Figure 1: Normalized effective $\mathrm{BO}$ defect density plotted as a function of the total boron concentration (a) or as a function of the majority carrier density (b).

Figure 2: (a): Majority carrier density measured by Hall effect along UMG-Si ingots Cz\#U1 and Cz\#U2. (b): Resistivity measured by 4-point probe along UMG-Si ingots Cz\#U1 and Cz\#U2.

Figure 3: Carrier lifetime measured by $\mu \mathrm{W}-\mathrm{PCD}$ along ingots Cz\#U1 and Cz\#U2.

Figure 4: Open-circuit voltage (a), short-circuit current (b) and conversion efficiency of solar cells made with wafers from Cz\#U1 and Cz\#U2 and from EG-Si control wafers.

Figure 5: Measured solar cell conversion efficiency on solar cells along Cz\#U1 and Cz\#U2 before and after light-induced degradation. 
[1] J. Schmidt, B. Lim, D. Walter, K. Bothe, S. Gatz, T. Dullweber, and P. P. Altermatt, "ImpurityRelated Limitations of Next-Generation Industrial Silicon Solar Cells," Photovoltaics, IEEE Journal of, vol. PP, pp. 1-5, 2012.

[2] R. Kopecek, J. Arumughan, K. Peter, E. A. Good, J. Libal, M. Acciarri, and S. Binetti, "Crystalline Si solar cells from compensated material: behaviour of light-induced degradation," in Proceedings of the 25th European Photovoltaic Solar Energy Conference, Valencia, Spain WIP, Munich, 2008.

[3] D. Macdonald, F. Rougieux, A. Cuevas, B. Lim, J. Schmidt, M. D. Sabatino, and L. J. Geerligs, "Light-induced boron-oxygen defect generation in compensated p-type Czochralski silicon," Journal of Applied Physics, vol. 105, p. 093704, 2009.

[4] B. Lim, F. Rougieux, D. Macdonald, K. Bothe, and J. Schmidt, "Generation and annihilation of boron--oxygen-related recombination centers in compensated p- and n-type silicon," Journal of Applied Physics, vol. 108, p. 103722, 2010.

[5] J. Geilker, W. Kwapil, and S. Rein, "Light-induced degradation in compensated p- and n-type Czochralski silicon wafers," Journal of Applied Physics, vol. 109, p. 053718, 2011.

[6] S. Bernardini, Saynova, S. Binetti, and G. Coletti, "Light-Induced Degradation in compensated mc-Si p-type solar cells," in Proceedings 38th IEEE Photovoltaic Specialists Conference, Austin, 2012.

[7] J. Kraiem, R. Einhaus, and H. Lauvray, "Doping engineering as a method to increase the performance of purified MG silicon during ingot crystallization," in Proceedings of the 34th IEEE Photovoltaic Specialists Conference, Philadelphia, 2009, p. 1327.

[8] M. Forster, E. Fourmond, R. Einhaus, H. Lauvray, J. Kraiem, and M. Lemiti, "Ga co-doping in Cz-grown silicon ingots to overcome limitations of B and P compensated silicon feedstock for PV applications," physica status solidi (c), vol. 8, pp. 678-681, 2011.

[9] M. Forster, B. Dehestru, A. Thomas, E. Fourmond, R. Einhaus, A. Cuevas, and M. Lemiti, "Compensation engineering for uniform n-type silicon ingots," Solar Energy Materials and Solar Cells, vol. 111, pp. 146-152, 2013.

[10] V. V. Voronkov and R. Falster, "Latent complexes of interstitial boron and oxygen dimers as a reason for degradation of silicon-based solar cells," Journal of Applied Physics, vol. 107, p. 053509, 2010.

[11] F. E. Rougieux, B. Lim, J. Schmidt, M. Forster, D. Macdonald, and A. Cuevas, "Influence of net doping, excess carrier density and annealing on the boron oxygen related defect density in compensated n-article silicon," Journal of Applied Physics, vol. 110, p. 063708, 2011.

[12] F. E. Rougieux, M. Forster, D. Macdonald, A. Cuevas, B. Lim, and J. Schmidt, "Recombination Activity and Impact of the Boron-Oxygen-Related Defect in Compensated N-Type Silicon," Photovoltaics, IEEE Journal of, vol. 1, pp. 54-58, 2011.

[13] V. V. Voronkov, R. Falster, K. Bothe, B. Lim, and J. Schmidt, "Lifetime-degrading boronoxygen centres in p-type and n-type compensated silicon," Journal of Applied Physics, vol. 110, pp. 063515-063515, 2011.

[14] M. Forster, E. Fourmond, F. E. Rougieux, A. Cuevas, R. Gotoh, K. Fujiwara, S. Uda, and M. Lemiti, "Boron-oxygen defect in Czochralski-silicon co-doped with gallium and boron," Applied Physics Letters, vol. 100, p. 042110, 2012. 
[15] A. Carvalho, P. Santos, J. Coutinho, R. Jones, M. J. Rayson, and P. R. Briddon, "Light induced degradation in B doped Cz-Si solar cells," physica status solidi (a), vol. 209, pp. 1894-1897, 2012.

[16] D. Macdonald, A. Liu, A. Cuevas, B. Lim, and J. Schmidt, "The impact of dopant compensation on the boron-oxygen defect in p- and n-type crystalline silicon," physica status solidi (a), vol. 208, pp. 559-563, 2011.

[17] F. Szmulowicz, "Calculation of the mobility and the Hall factor for doped p-type silicon," Phys. Rev. B, vol. 34, pp. 4031--4047, Sep 1986.

[18] E. Scheil, "Bemerkungen zur Schichtkristallbildung," Z. metallk., vol. 34, pp. 70-70, 1942.

[19] R. A. Sinton and A. Cuevas, "Contactless determination of current--voltage characteristics and minority-carrier lifetimes in semiconductors from quasi-steady-state photoconductance data," Applied Physics Letters, vol. 69, pp. 2510-2512, 1996.

[20] F. Dannhäuser, J. Krausse, and K. Mayer, "Zum einfluss von temperprozessen auf widerstandsschwankungen in siliziumeinkristallen," Solid-State Electronics, vol. 15, pp. 13831384, 1972.

[21] J. Krausse, "Die abhängigkeit der trägerbeweglichkeit in silizium von der konzentration der freien ladungstrager - II," Solid-State Electronics, vol. 15, pp. 1377-1381, 1972.

[22] P. P. Altermatt, J. Schmidt, M. J. Kerr, G. Heiser, and A. G. Aberle, "Exciton-enhanced Auger recombination in crystalline silicon under intermediate and high injection conditions," in Proceedings of the 16th European Photovoltaic Solar Energy Conference, Glasgow, Wales, 2000.

[23] F. E. Rougieux, P. Zheng, M. Thiboust, J. Tan, N. E. Grant, D. H. Macdonald, and A. Cuevas, "A Contactless Method for Determining the Carrier Mobility Sum in Silicon Wafers," Photovoltaics, IEEE Journal of, vol. 2, pp. 41-46, 2012.

[24] M. Forster, F. E. Rougieux, A. Cuevas, B. Dehestru, A. Thomas, E. Fourmond, and M. Lemiti, "Incomplete Ionization and Carrier Mobility in Compensated p-Type and n-Type Silicon," Photovoltaics, IEEE Journal of, vol. 3, p. 108, 2013.

[25] J. Schmidt and K. Bothe, "Structure and transformation of the metastable boron- and oxygenrelated defect center in crystalline silicon," Phys. Rev. B, vol. 69, p. 024107, 2004.

[26] L. I. Murin, T. Hallberg, V. P. Markevich, and J. L. Lindstr|"om, "Experimental Evidence of the Oxygen Dimer in Silicon," Phys. Rev. Lett., vol. 80, pp. 93--96, Jan 1998.

[27] J. Kraiem, B. Drevet, F. Cocco, N. Enjalbert, S. Dubois, D. Camel, D. Grosset-Bourbange, D. Pelletier, T. Margaria, and R. Einhaus, "High performance solar cells made from 100\% UMG silicon obtained via the Photosil process," in Proceedings of the 35th IEEE Photovoltaic Specialists Conference, Hawaï, 2010.

[28] D. Sarti and R. Einhaus, "Silicon feedstock for the multi-crystalline photovoltaic industry," Solar Energy Materials and Solar Cells, vol. 72, pp. 27-40, 2002.

[29] R. Einhaus, J. Kraiem, F. Cocco, Y. Caratini, D. Bernou, D. Sarti, G. Rey, R. Monna, C. Trassy, J. Degoulange, Y. Delannoy, S. Martinuzzi, I. Périchaud, M. C. Record, and P. Rivat, "PHOTOSIL - Simplified Production of Solar Silicon from Metallurgical Silicon," in Proceedings of the 21st European Photovoltaic Solar Energy Conference, Dresden, Germany, WIP, Munich, 2006.

[30] J. Libal, S. Novaglia, M. Acciarri, S. Binetti, R. Petres, J. Arumughan, R. Kopecek, and A. Prokopenko, "Effect of compensation and of metallic impurities on the electrical properties of Cz-grown solar grade silicon," Journal of Applied Physics, vol. 104, p. 104507, 2008. 
[31] S. Dubois, N. Enjalbert, and J. P. Garandet, "Effects of the compensation level on the carrier lifetime of crystalline silicon," Applied Physics Letters, vol. 93, p. 032114, 2008.

[32] D. Macdonald and A. Cuevas, "Recombination in compensated crystalline silicon for solar cells," Journal of Applied Physics, vol. 109, pp. 043704-043704, 2011.

[33] S. Rein and S. W. Glunz, "Electronic properties of the metastable defect in boron-doped Czochralski silicon: Unambiguous determination by advanced lifetime spectroscopy," Applied Physics Letters, vol. 82, pp. 1054-1056, 2003.

[34] D. Macdonald and A. Cuevas, "Recombination in compensated crystalline silicon for solar cells," Journal of Applied Physics, vol. 109, p. 043704, 2011. 


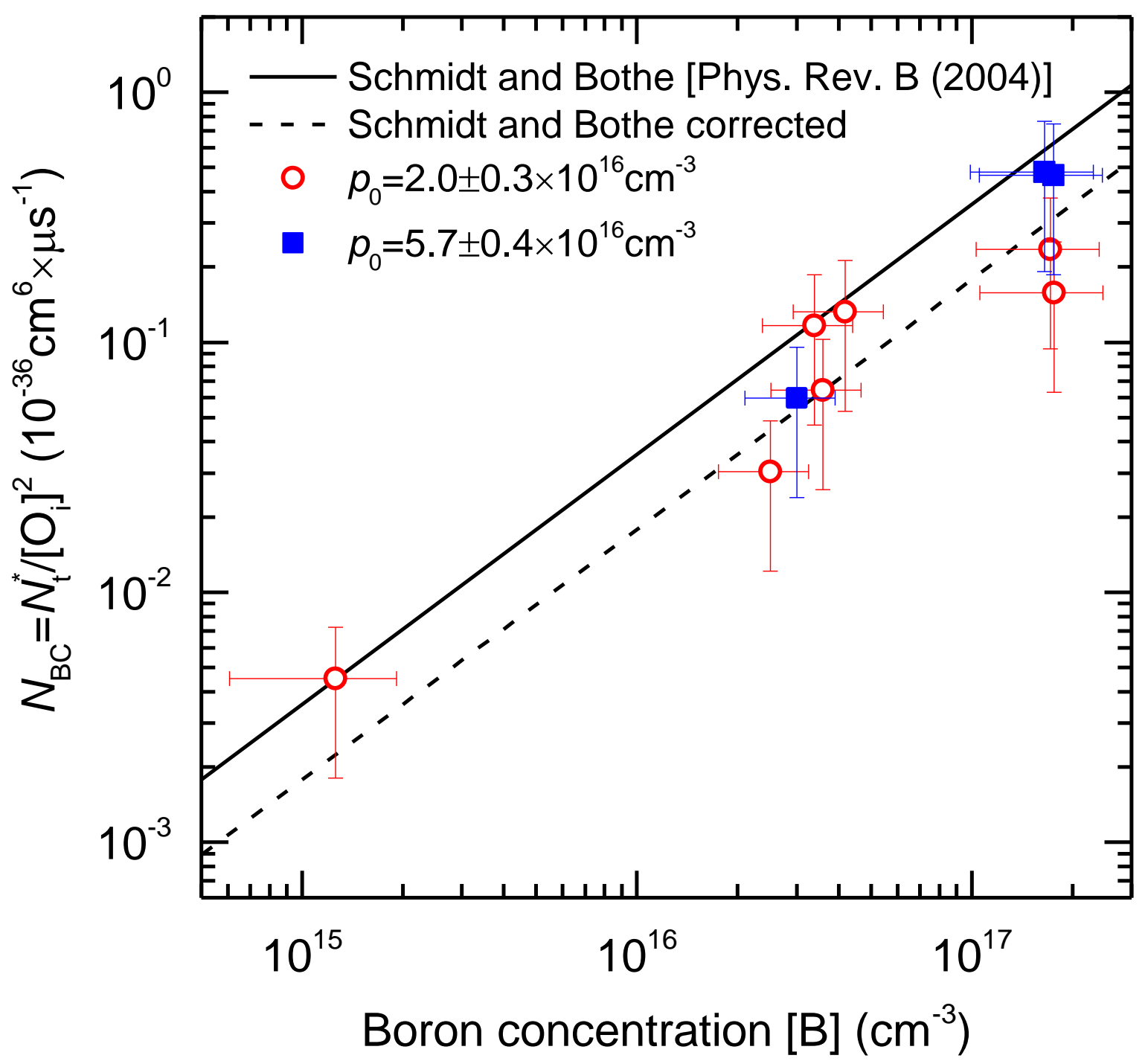




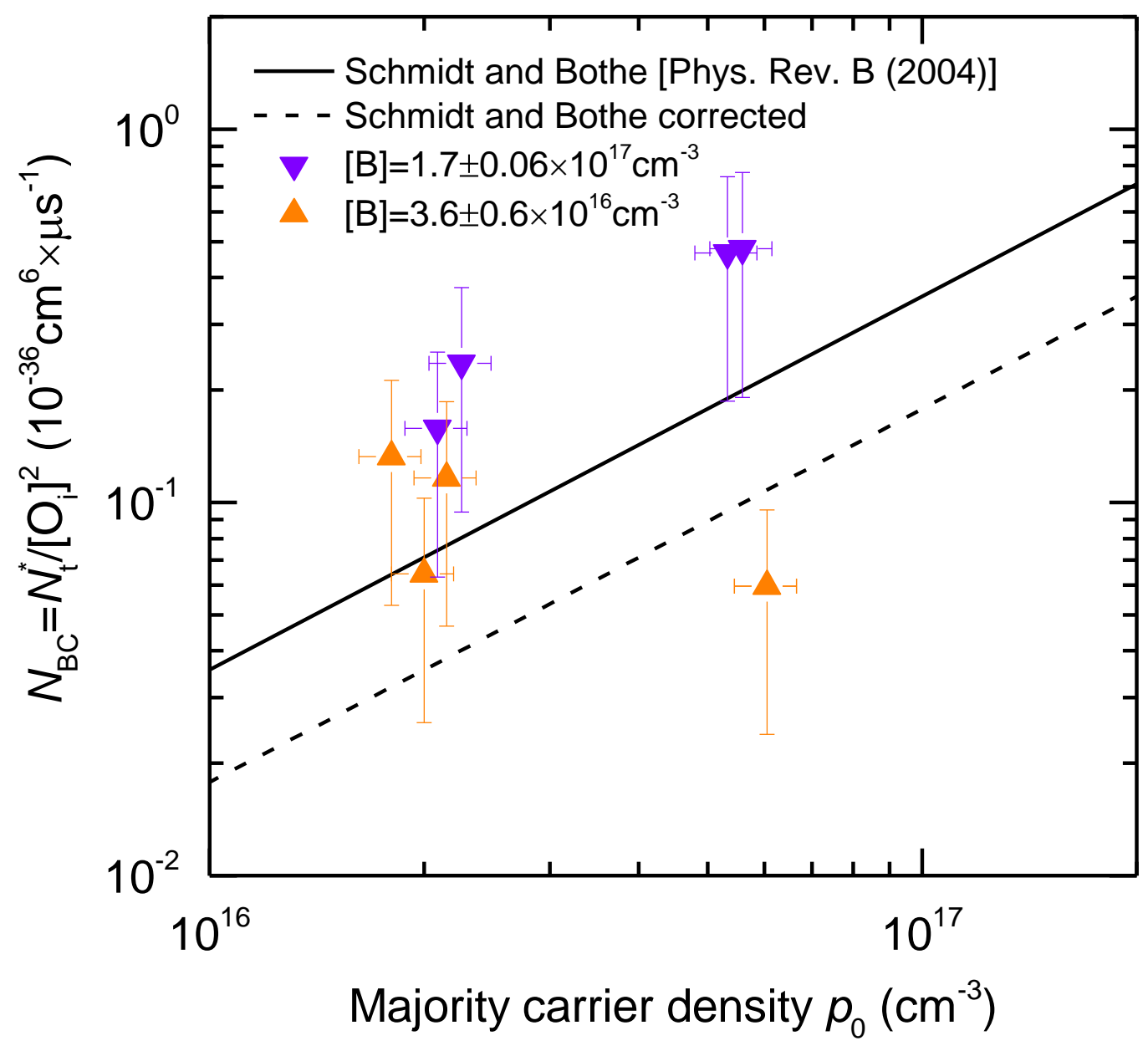


Figure 2 a

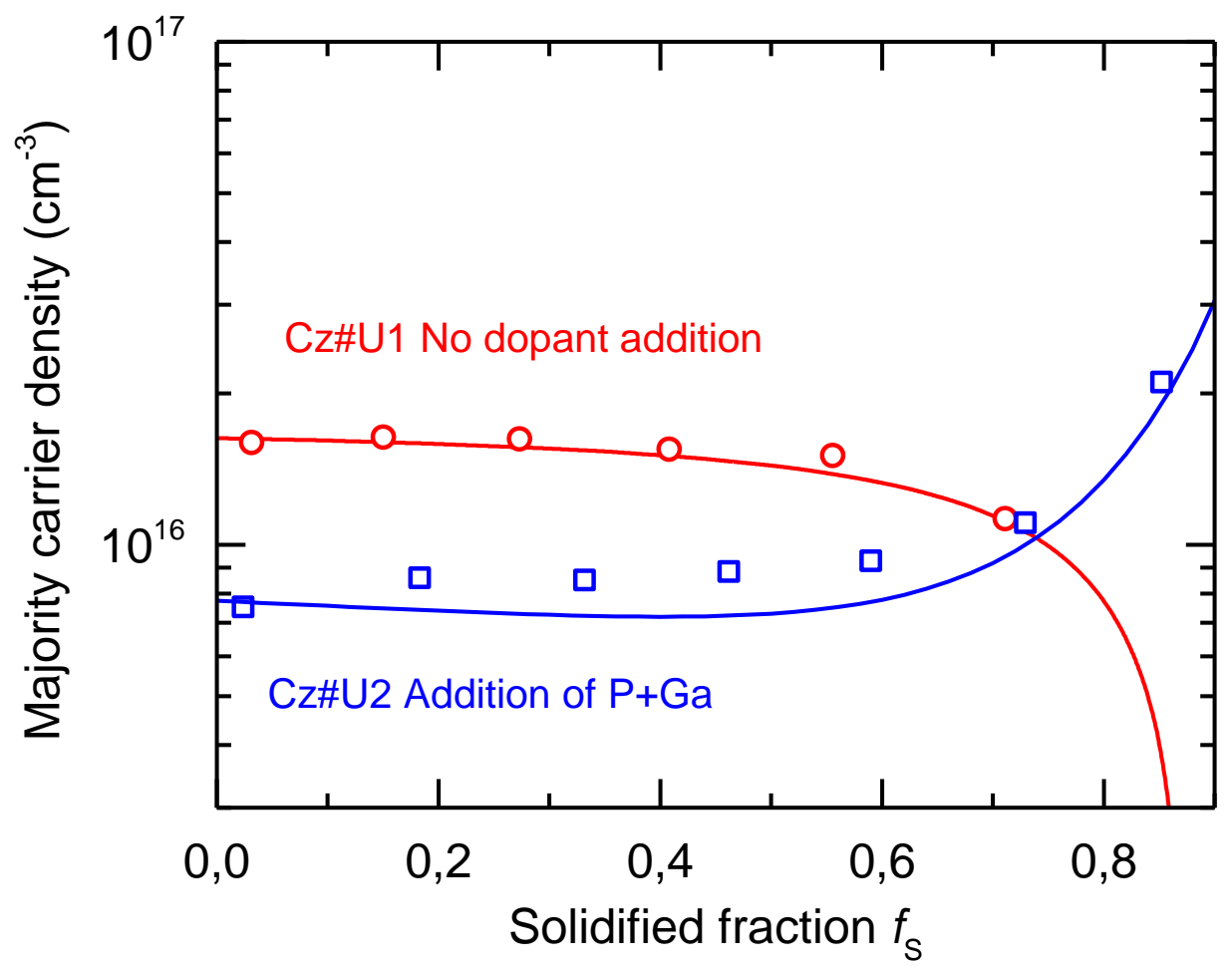


Figure 2 b

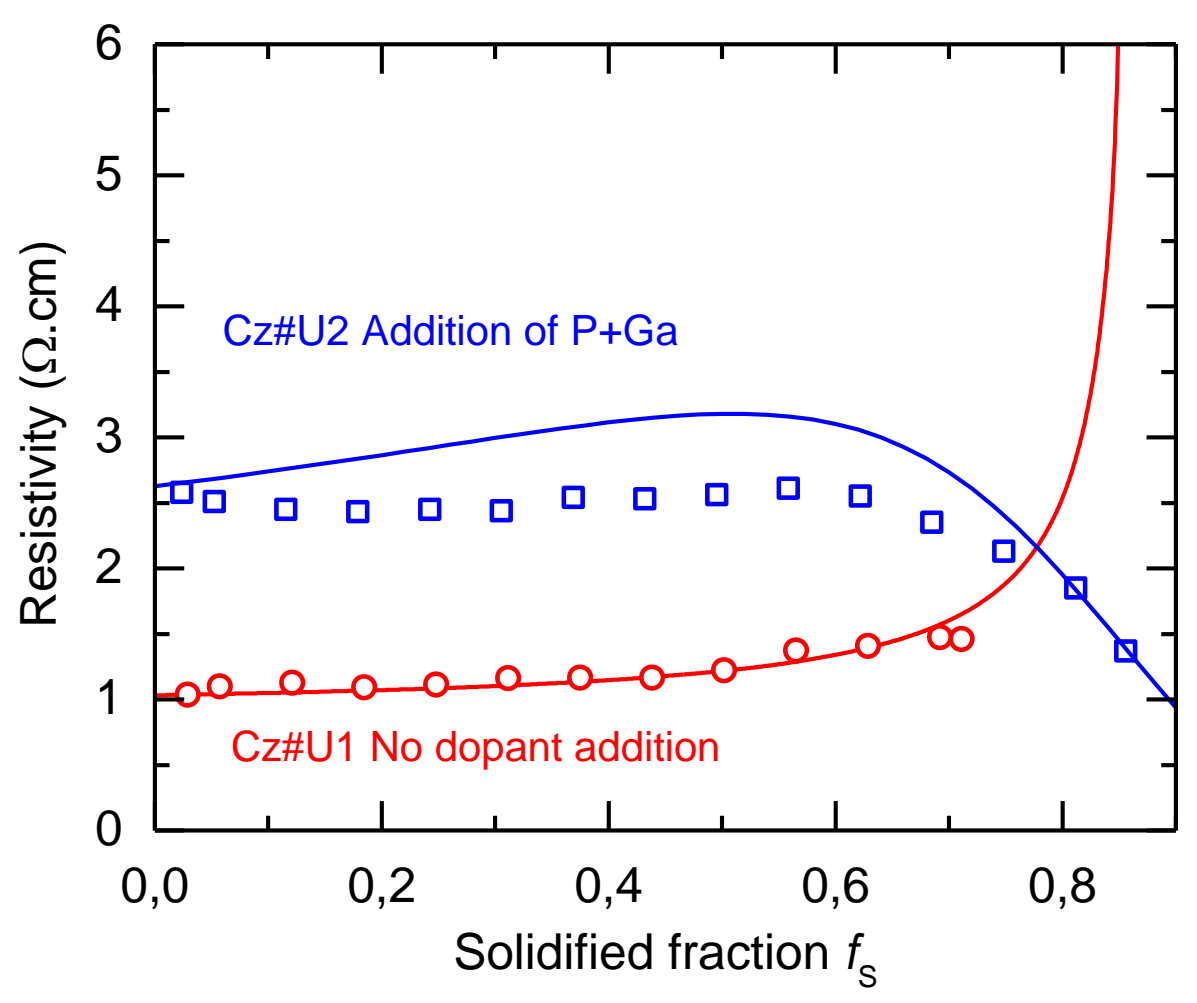




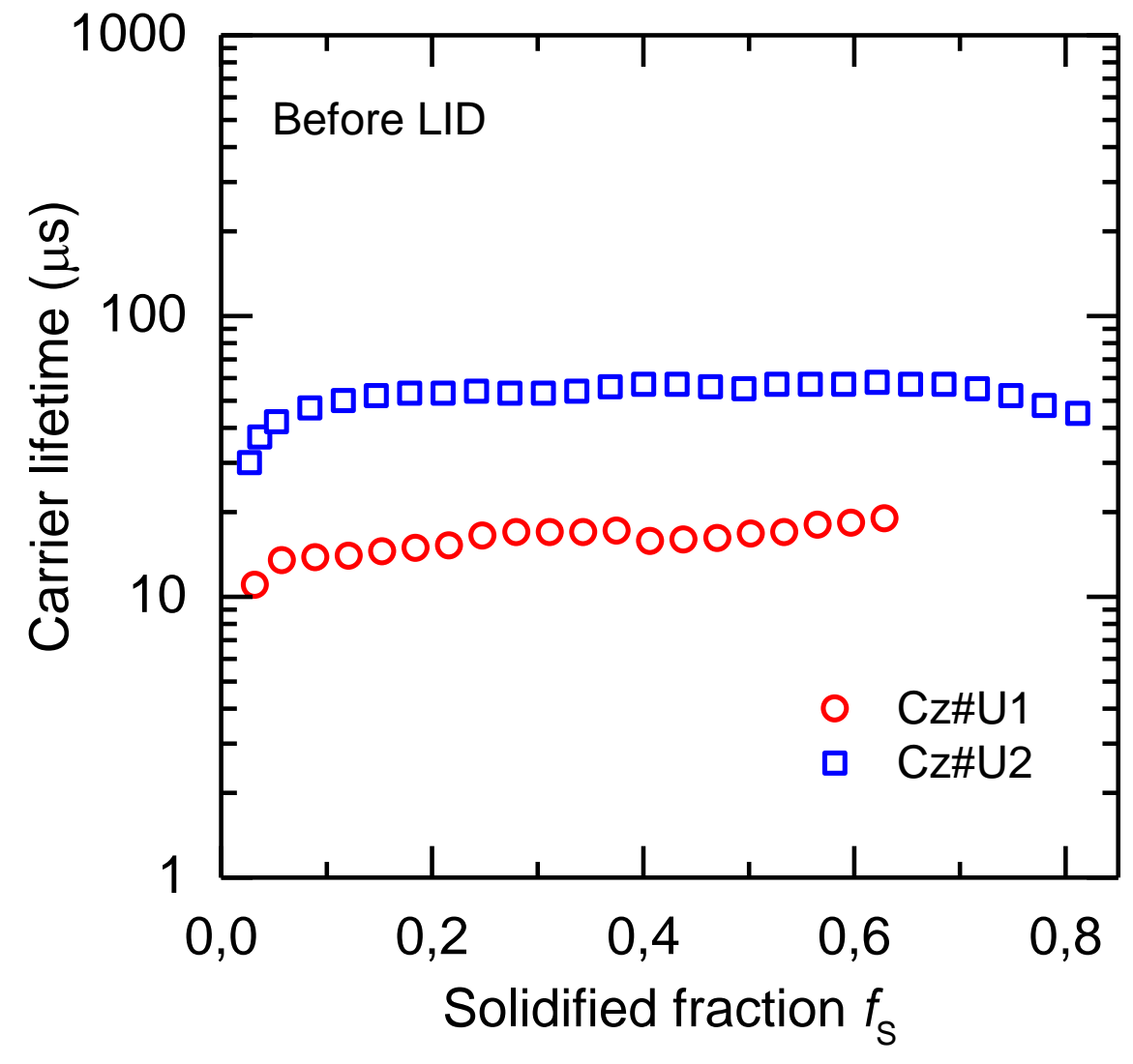


Figure 4 a

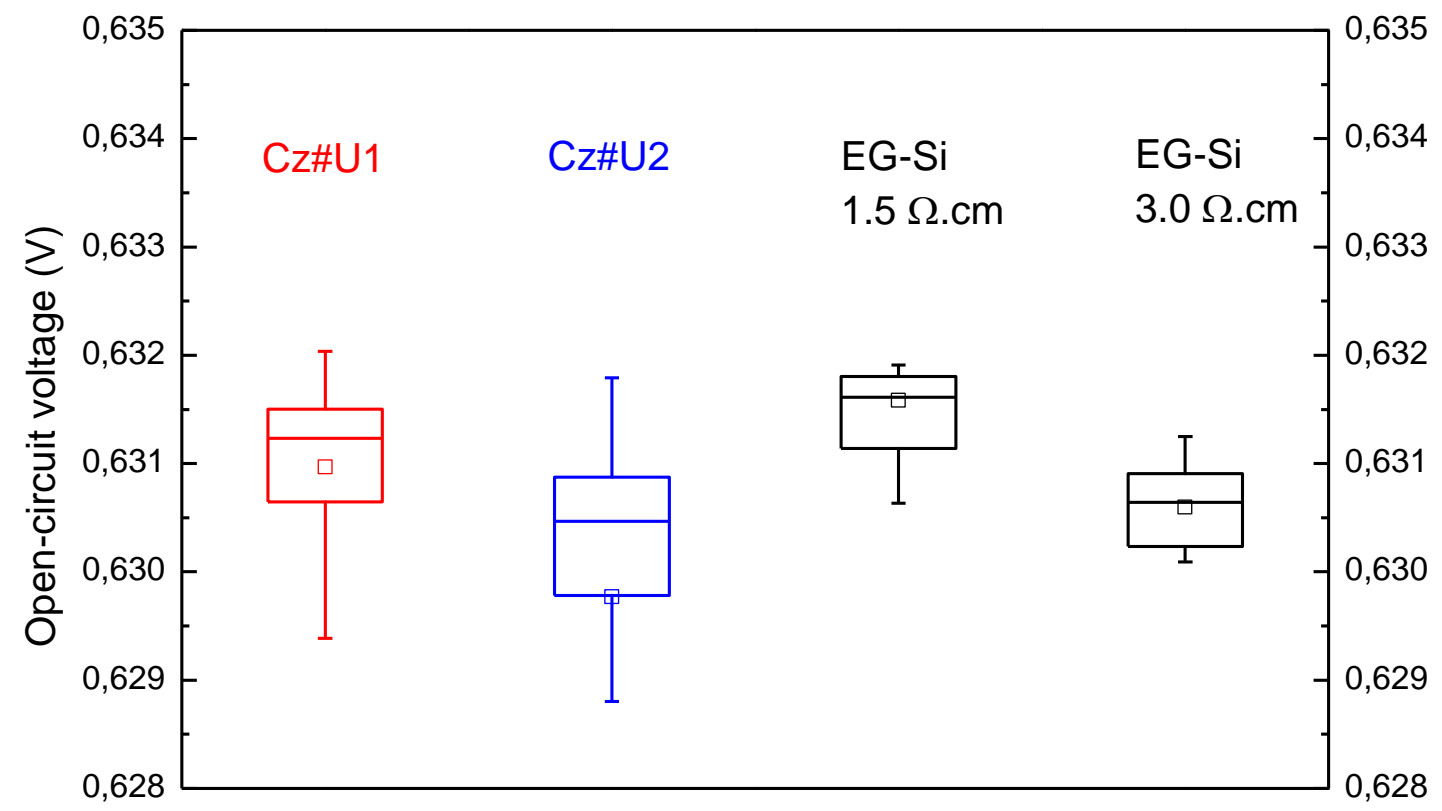


Figure $4 \mathrm{~b}$

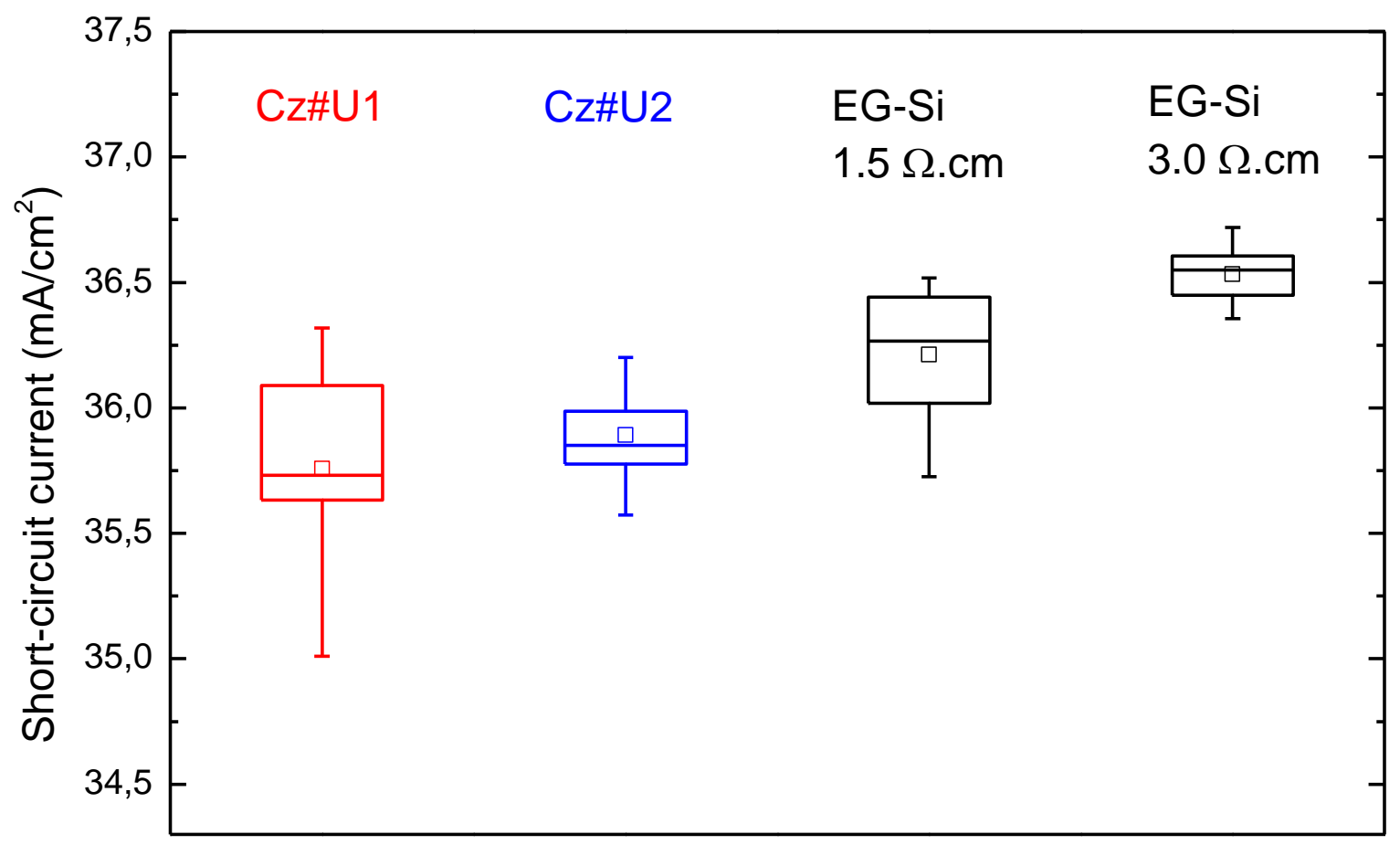


Figure $4 \mathrm{c}$

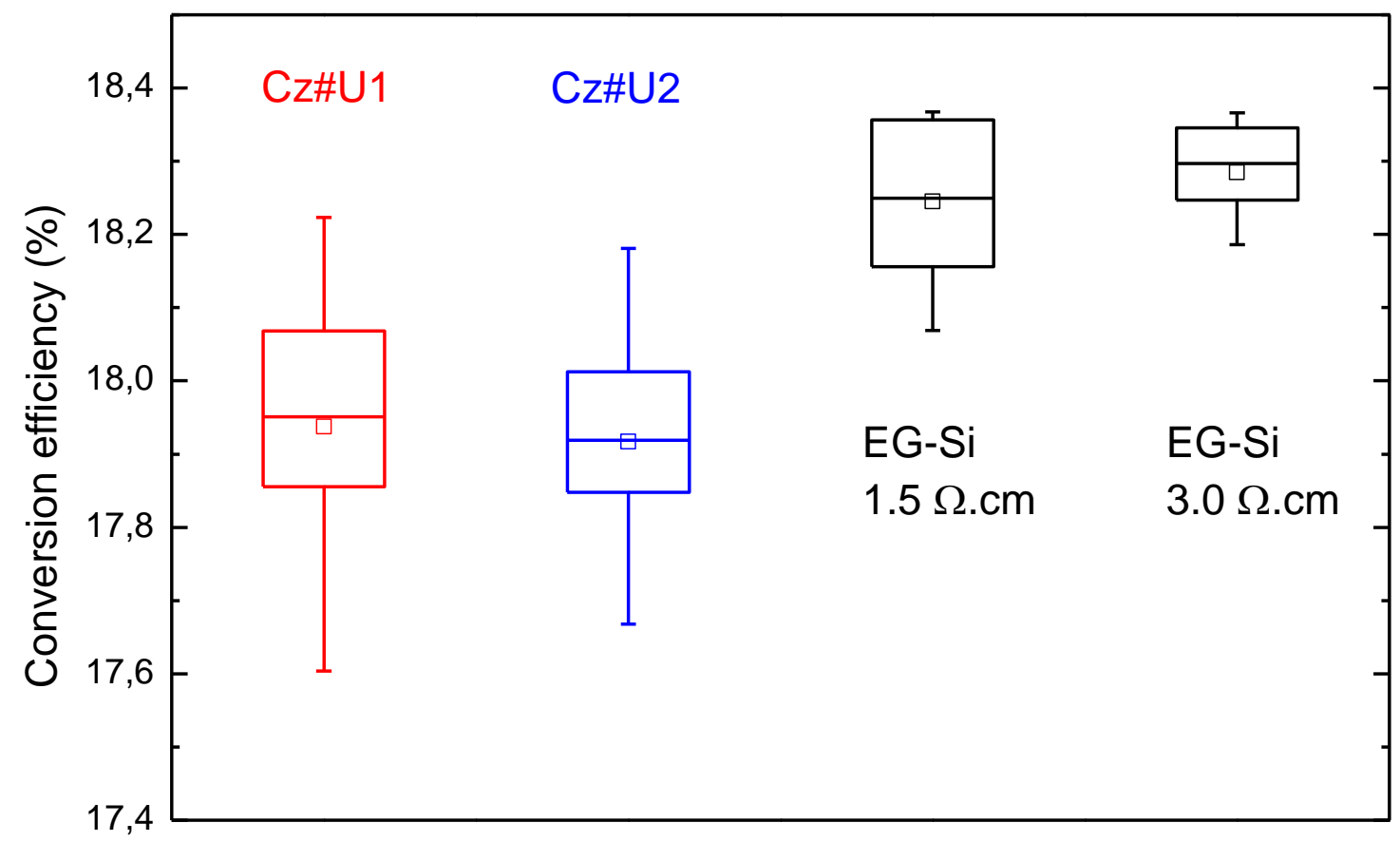


Figure 5

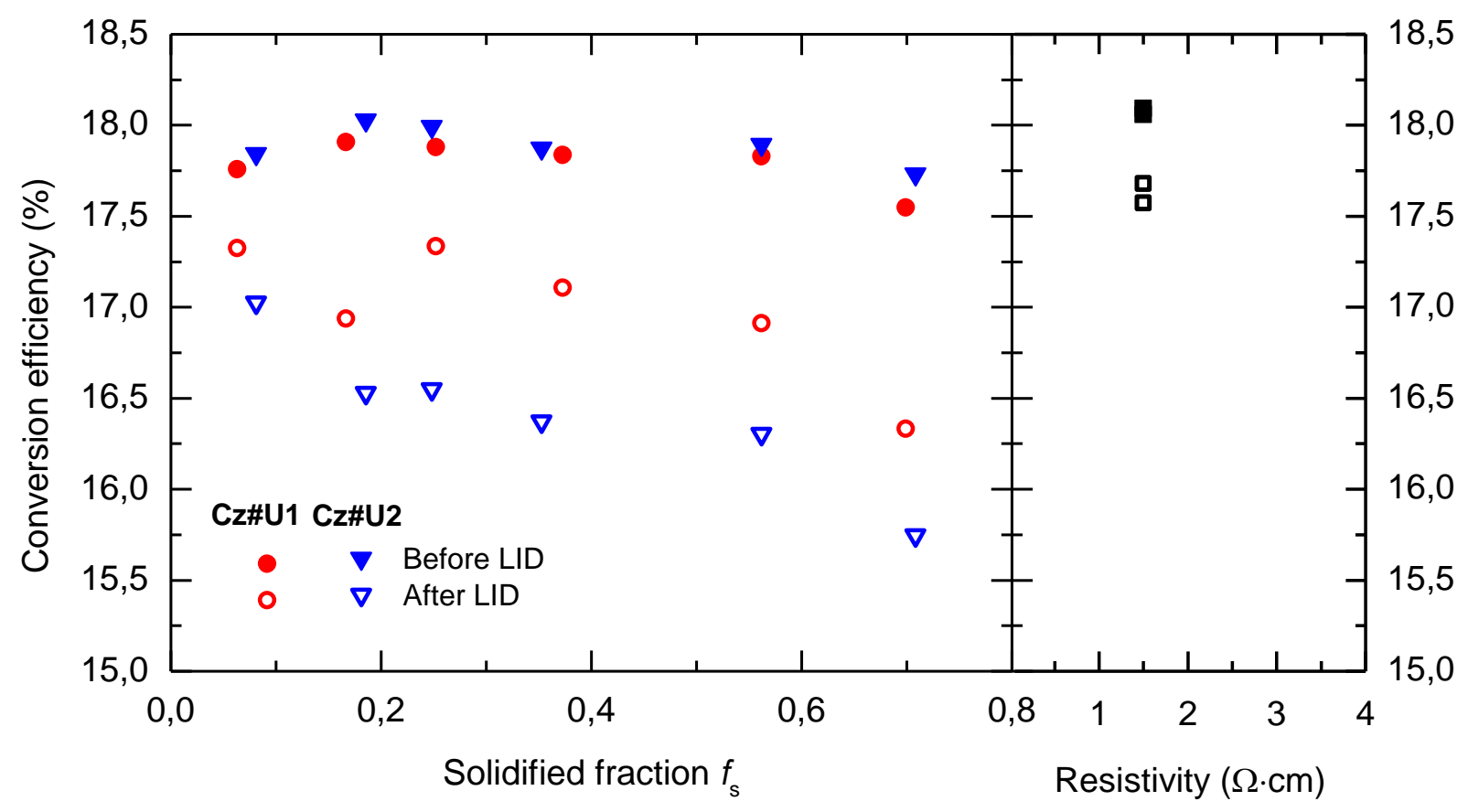

